NASA Technical Memorandum 83349

AIAA-83-0680

\title{
A Compact Inflow Control Device for Simulating Flight Fan Noise
}

L. Homyak, J. G. McArdle, and L. J. Heidelberg

Lewis Research Center

Cleveland, Ohio

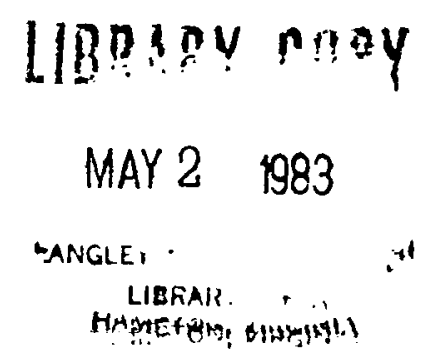

Prepared for the

Eighth Aeroacoustics Conference

sponsored by the American Institute of Aeronautics and Astronautics Atlanta, Georgia, April 11-13, 1983

\section{N/SA}


31176013278388 


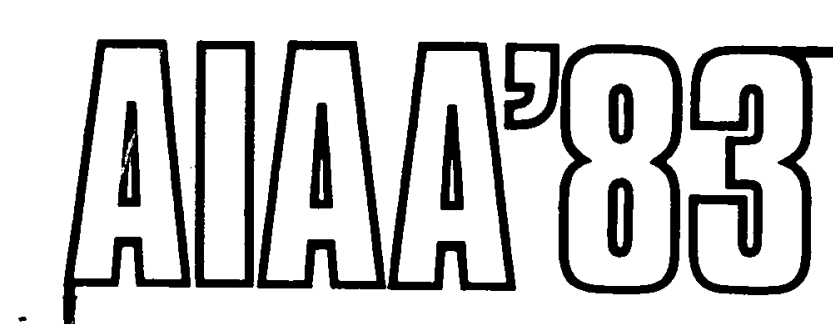

\title{
AIAA-83-0680
}

A Compact Inflow Control Device for

Simulating Flight Fan Noise

L. Homyak, J.G. McArdle and

L.J. Heidelberg, NASA Lewis Research Center,

Cleveland, $\mathrm{OH}$

\author{
LERARY moy \\ MAY $2 \quad 1983$ \\ LanGLLT 'U. SËAR. \\ LICRARY, NA.. \\ MAITPTON, VIFEIPI!
}

\section{AIAA 8th Aeroacoustics Conference}

April 11-13, 1983 / Atlanta, Georgia 


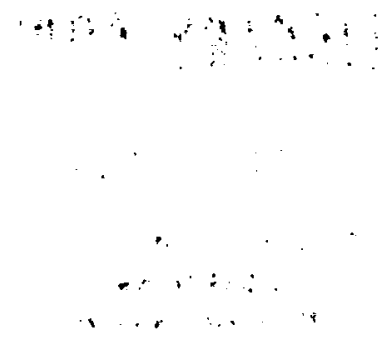




\author{
L. Homyak, J. G. McArdle, and L. J. Heidelberg \\ National Aeronautics and Space Administration \\ Lewis Research Center \\ Cleveland, Ohio 44135
}

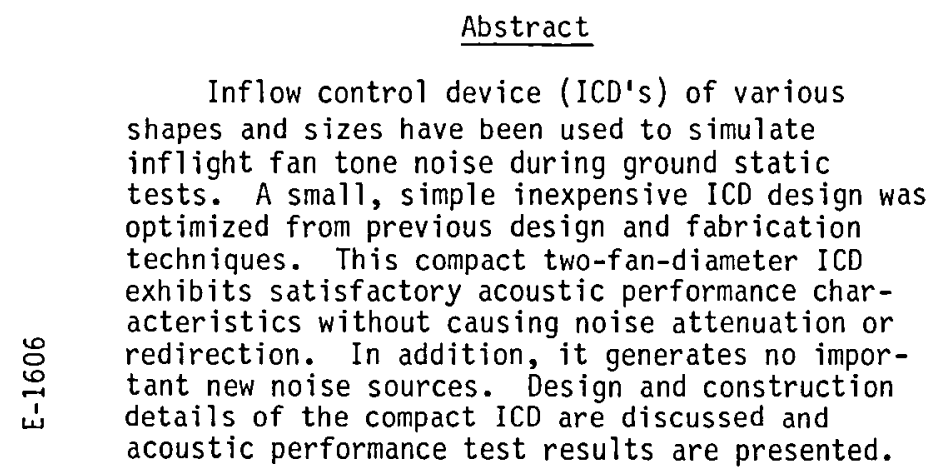

\section{Introduction}

During ground static testing of jet engines, atmospheric turbulence which undergoes vortex stretching and other inflow disturbances not present in flight can cause strong tone noise by interaction with the fan rotor. It is necessary to eliminate these noise sources to measure the engine's "real" acoustic characteristics. The inflow disturbances and noise caused by them can be removed by a honeycomb structure, herein called an "inflow control device " (ICD), mounted over the test engine inlet. The NASA Lewis Research Center has designed and tested several ICD's of different size, shape, and construction. $1-6$ As a culmination of this experience a new ICD, incorporating the best features of the previous designs, was built and its performance was evaluated with the JT15D-] business jet engine. The objective was to make a relatively inexpensive ICD having satisfactory acoustic performance, while being significantly smaller, lighter, and simpler than the large cumbersome structures currently used for commercial ground testing. The compact ICD was made to mount on the same engine inlet shape used in the NASA inter-center "Forward Velocity Effects on Fan Noise" program reported in references 6 and 7 . This feature permits ICD tests on similar JT15D-1 engines to enable better comparison of flight and ground test results.

In this paper, design and construction details of the ICD are discussed, and results of acoustic performance tests are presented for a range of fan speeds. The tests included far-field directivity tests, acoustic transmission tests, and tests to determine if any significant new acoustic sources were created by the presence of the ICD on the engine inlet.

\section{Apparatus and Instrumentation}

\section{ICD and Inlet}

Major design criteria and their impact on the ICD were as follows:

A. Negligible acoustic transmission losses Use a reasonable size with shape to keep honeycomb cells undistorted and aligned with the flow;

B. Minimize wakes from the structure - Use thin support $r$ ibs with meticulous workmanship on joints;
C. Minimize flow disturbances at mounting points - Attach at low-velocity flow region with smooth cowling and highlight;

$D$. Strong and lightweight - Use the smallest ICD size consistent with good acoustic performance and use honeycomb thick enough to carry some structural load;

E. Simplicity - Avoid screens, perforated plates and need for complex handling equipment to ease installation.

The resulting design is shown in figure 1(a). It is about two fan diameters in size, and is mounted from a machined area on the cowling surface. The ICD was made from nine triangular sections of $5 \mathrm{~cm}$ (2-in.) thick flexible honeycomb with a nominal $0.6 \mathrm{~cm}(0.25-i$. $)$ cell size. Each section was formed and trimmed over a mold; then the edges were epoxied neatly to $0.04 \mathrm{~cm}(0.015-$ in.) thin stainless steel ribs. Adjacent ribs were spotwelded together, forming a self-supporting structure as shown in figure 2. The contour was designed so that the honeycomb cells were aligned with streamlines calculated by a potential flow analysis.

The ICD installed on a flight type inlet and cowling is shown in figure $](b)$. The inlet has a 1.5-degree conical diffuser downstream of the throat. The lip is a 2:1 ellipse, and fairs into a 15-degree conical cowling. The diffuser, throat, and lip were the same as used in both the ground and flight tests. Potential flow analyses predicted no inlet flow separation in low-level flight or in ground static tests.

\section{Engine and Facility}

The test engine was an early production Pratt and Whitney JT15D-1 turbofan with a rated thrust of $9800 \mathrm{~N}(2200 \mathrm{jb})$, and nominal bypass ratio of 3.3. The fan is $53.3 \mathrm{~cm}$ in diameter (2l-in.) and has 28 blades and develops a 1.5 pressure ratio at $15500 \mathrm{rpm}$. Six structural struts located aft of the stators support the core engine from the outer case. The engine was modified so that fan rotor-core stator interaction tones would be acoustically cut-off. This was accomplished by increasing the core stator vane number from 33 to 71 vanes while maintaining equivalent aerodynamic performance. As an additional acoustic consideration, the rotor-core stator separation was increased to 0.63 rotor root chord lengths. The detailed engine description and modifications are described in reference 2 .

A picture of the engine on the test stand is shown in figure 3 . The test engine was suspended from a thrust measuring system on a cantilevered pylon support arm. The support arm faired smooth$l y$ into the engine cowling and positioned the engine inlet greater than 3.4 diameters from any facility or ground structure. The engine exhausts into a large muffler to prevent noise contamination from aft fan or jet noise. The $2.8 \mathrm{~m}$ (9.3-ft) diameter by $18.3 \mathrm{~m}(60-\mathrm{ft})$ long muffler is shown attached to the engine. Figure 4 shows the compact ICD installed on the JTI5D-l engine. 


\section{Instrumentation}

The procedure and instrumentation used for previous tests with other ICD's described in references 2 and 3 were also used for the compact two-fan-diameter ICD. Acoustic measurements were made form $10^{\circ}$ to $90^{\circ}$ about the engine inlet by $1.3 \mathrm{~cm}(0.5-i n$.$) farfield ground microphones on a$ $24.4 \mathrm{~m}(80-\mathrm{ft})$ radius circle. The test facility with acoustic arena is shown in figure 5 . The microphone signals were gain adjusted to a signal level less than 1 volt rms, and recorded on frequency modulated (F.M.) tape. A fast Fourier transform spectrum analyzer converted signals to a narrow- band spectra using 20 second samples of recorded data to obtain a 400-1 ine spectra with a bandwidth of $25 \mathrm{~Hz}$. Ground microphone results were corrected to $30.5 \mathrm{~m}(100-\mathrm{ft})$ free field radial distance and standard-day temperature $\left(15^{\circ} \mathrm{C}\right)$ and relative humidity $(70 \%)$ conditions. The engine was also instrumented with miniature blade mounted pressure transducers. Fabrication details and response characteristics of the installed transducers are given in reference 8. The transducers sense pressure changes on the rotating blade surface. Pressure data were transmitted from the engine by telemetry. The transducers, their location, operation and data analysis procedure are described in reference 2.

\section{Results and Discussion}

\section{Far-Field Directivity Patterns}

Mode propagation characteristics for this engine are shown in figure 6 . The modal cut off values were calculated from conventional TylerSofrin theory. ${ }^{9}$ This figure displays the modal cut-off values based on both the fan face and inlet throat diameters.

The fan blade passing frequency (BPF) modes which are most likely to affect the directivity patterns are: $M=22$, from interaction between 28 fan blades and 6 engine structural struts; $M=19$, from interaction between 28 fan blades and 9 ICD ribs and sections; and $M=-13$, from interaction between $28 \mathrm{fan}$ blades and 41 inlet rod wakes present in acoustic transmission tests.

Far-field BPF directivity patterns for the engine with and without the ICD installed are shown in figure 7 . At $9700 \mathrm{rpm}$ there is almost no tone with the ICD installed, showing that it effectively removed tone noise arising from the inflow disturbances and turbulence. At this speed the $M=19$ mode is just cut-on, and there appears to be a weak lobe peaking at about $60^{\circ}$. This tone (considered insignificant) originates from rotor/rib wake interaction. At $10800 \mathrm{rpm}$ (fig. $7(b))$ the $M=22$ mode is just cut-on, and also causes a lobe near the $60^{\circ}$ angle. This lobe has been obseryed in many previous tests with this engine.2, 11 The fan tip speed at $13500 \mathrm{rpm}$ is supersonic and noise from the $M=28$ mode, due to the rotor-alone field, dominates the sideline angles. Even with the ICD, the noise at this speed increases to the no ICD level because the ICD does not affect tones generated by a source which is not related to inflow distortions.

\section{Acoustic Transmission Tests}

\section{ICD acoustic transmission characteristics} were checked with a controlled source which was independent of inflow conditions. This controlled source was generated by wakes from 41 rods pro- truding $6.4 \mathrm{~cm}(2.5-i n$.$) from the inlet wall about$ 20 rod diameters upstream of the rotor face. The rods were $0.5 \mathrm{~cm}(3 / 16-i n$.$) diameter. The rod$ installation is further described in reference 2. Rotor interaction with the rod wakes produced the $M=-13$ spinning mode which dominates the noise directivity pattern.

Results of these acoustic tests with the inlet rod-rotor interaction noise source show the ICD to have little effect on the transmitted noise. This conclusion is supported by the directivity results of figure 8 . At $10800 \mathrm{rpm}$ (fig. 8(a)) the rod-induced tone peaks at $45^{\circ}$ and has essentially the same value with or without the ICD present. The ICD did somewhat reduce the tone level away from this lobe, as might be expected for inflow disturbance generated noise. At $13500 \mathrm{rpm}$ (fig. 8(b)) the rod induced noise is further cut-on and peaks more toward the forward angles. At this speed the fan tip speed is supersonic and the $M=28$ mode due to the rotor alone is also cut-on. This mode, which tends to propagate toward the sideline angles is evident from $60^{\circ}$ to $90^{\circ}$ in figure $8(\mathrm{~b})$. Again the ICD offers no attenuation to this internally-generated tone. Had the ICD caused transmission losses, the sound pressure level (SPL) of the lobe peak with the ICD would have been lower than the peak obtained without an ICD. The peak with the ICD is actually slightly higher. The differences shown in both figures $8(a)$ and (b) may be related to the fact that the engine speed is inherently less stable without an ICD. Narrow band analys is for noise from a fan with varying speed causes the frequency of the BPF tone to shift across analysis bands. This results in a tone peak that is lower and broader compared to a narrow tone obtained at a more stable engine speed where band splitting does not occur.

At each speed the ICD reduced the tone levels associated with rotor-inflow distortion interaction, but the principal lobe from the $M=-13$ mode produced by the rod wake mechanism is essentially the same with and without the ICD installed. In addition, the broadband noise level and directivity are unchanged when the ICD is installed. The patterns thus show that the ICD does not attenuate or redirect noise passing through it from the fan to the far field.

Tests for New Noise Sources

Spectral data from the blade mounted transducers were used to determine if the presence of the ICD created any flow distortions which could act as new sources of BPF tone noise. These data were obtained from the B-3 transducer described in reference 2. B-3 was located $2 \mathrm{~cm}(0.75 \mathrm{in.})$ in from the blade tip near the leading edge of the pressure surface. Typical spectra for $10500 \mathrm{rpm}$ are shown in figure 9 . Without the ICD the spectrum consists of a series of spikes which occur at multiples of shaft rotation frequency and extend above the broadband base with roughly equal amplitude. This type of spectrum indicates the presence of randomly occurring, but axially persistent inflow disturbances (turbulence) which produce narrow band random tone noise by interaction with the fan rotor. With the ICD installed, strong spikes appear only at distortion numbers $(g)$ of 1 , 6 , and 12, and weaker spikes at $q=9,14$, and 17. The $q=1$ spike is observed in all tests at this facility, and may be caused by the ground plane (although the engine centerline is $5-1 / 2$ engine $f$ an diameters from the ground). The $q=6$ 
and 12 spikes are believed to be caused by the potential field from the six engine struts, and are observed ${ }^{10}$ in other tests with this engine. The $q=9$ spike is associated with wakes from the nine ICD ribs. The $q=14$ and 17 spikes are not accounted for, but their strengths are about the same as the $q=9$ spike which caused only a small tone lobe in the far field. Therefore, by inference, the $q=14$ and 17 spikes do not represent important new noise sources.

\section{Test for Rib Thickness Effect}

Results of a test to study ICD rib width effect on far field fan noise are shown in figure 10. For this test, aluminum tape strips $5 \mathrm{~cm}$ $(2-i n$.$) wide were placed outside of the honeycomb$ over each of the nine ribs to simulate thick ribs. At $9700 \mathrm{rpm}$, the $M=19$ mode due to nine rib-rotor interaction is just cut-on, so a large lobe was expected near $60^{\circ}$ in the directivity pattern. In fact, figure 10 shows that the simulated thick ribs produced only small changes in tone levels.

Blade pressure spectra were examined to determine whether the tape strips produced a significant change in the $q=9$ distortion sensed on the rotor. Spectra from blade mounted transducer $B-3$ are compared in figure 11. Only a weak spike is observed at $q=9$ regardless of whether the ribs were taped. This result agrees with the low tone levels and insensitivity to rib taping observed. Perhaps the fact that the tape was placed outside the honeycomb resulted in a poor simulation of potential rib thickness effects. In reference 10, experimental results comparing the effectiveness of the same ICD with another ICD of similar size but inferior construction confirmed the superiority of the present design. Boundary layer suction experiments also reported in reference 10 indicated that the acoustic performance of the inferior design could be improved by removing the disturbed flow near the wall and implied that construction details in mating the ICD to the cowl could be particularly important.

\section{Conclusions}

The new inflow control device (ICD) built and demonstrated for the JTI5D-1 engine exhibits: (a) Satisfactory acoustic performance characteristics; (b) No acoustic attenuation or redirection for tone or broadband noise; and (c) No important new noise sources associated with the ICD installation. Also, the new ICD is small, lightweight, strong, and simple to build and handle in contrast to the cumbersome structures used in commercial testing. Previous results ${ }^{2}$ showed that there was a negligible pressure drop across the ICD and that fan aerodynamic operation was unaffected.
In terms of acoustic performance, the fan tone levels measured with this ICD on the outdoor engine test stand agree well with flight data for this engine as reported in reference 7 . Finally, experiments in an anechoic chamber with the same ICD and fan have shown essentially the same acoustic results 10 indicating the wider applicability of the inflow control design. It is believed that this ICD represents the successful culmination of ICD research at the Lewis Research Center.

The design principles and construction techniques developed and employed in this program should be applicable to any engine or fan static test instaliation. Since engine fan specific inflow rates do not vary appreciably it appears that selection of the ICD diameter equal to twice the fan diameter should be acceptable for scaling purposes. Also selection of the same honeycomb thickness and cell size should be more than adequate for larger installations. If necessary, for structural purposes, the number of support ribs and honeycomb segments could be increased. In construction, care should be used in the fitting of the honeycomb segments and, more importantly, in the mating of the ICD to the nacelle.

\section{References}

1. McArdle, J. G., Homyak, L., and Chrulski, D. D., "Turbomachinery Noise Studies of the AiResearch QCGAT Engine with Inflow Control," AIAA Paper 81-2049, 0ct. 1981.

2. McArdle, J. G., Jones, W. L., Heidelberg, L. J., and Homyak, L., "Comparison of Several Inflow Control Devices for Flight Simulation of Fan Tone Noise Using a JT15D-1 Engine," NASA TM-81505, 1980.

3. Jones, W. L., McArdle, J. G., and Homyak, L., "Evaluation of Two Inflow Control Devices for Flight Simulation of Fan Noise Using a JT150 Engine," AIAA Paper 79-0654, Mar. 1979.

4. Woodward, R. P., Wazyniak, J. A., Shaw, L. M., and Mackinnon, M. J., "Effectiveness of an Inlet Flow Turbulence Control Device to Simulate Flight Fan Noise in an Anechoic Chamber, "NASA TM-73855, 1977.

5. Woodward, R. P., and Glaser, F. W., "Effect of Inflow Control on Inlet Noise of a Cut-on Fan," AIAA Paper 80-1049, June 1980.

6. Chestnutt, D., "Flight Effects of Fan Noise," NASA CP-2242, 1982.

7. Preisser, J. S., and Chestnutt, D., "Flight Effects on Fan Noise with Static and Wind Tunnel Comparisons," AIAA Paper 83-0678, 1983.

8. Englung, D. R., Grant, H. P., and Lanati, G. A., "Measuring Unsteady Pressure on Rotating Compressor Blades," NASA TM-79159, 1979.

$$
\text { 9. Tyler, J. M., and Sofrin, T. G., "Axial }
$$

Flow Compressor Noise Studies," SAE Transaction, Vol. 70, 1962, pp. 309-332.

10. Woodward, R. P., and Balombin, J. R., "Tone Generation by Rotor-Downstream Strut Interaction," AIAA Paper 83-0767, 1983. 
$5 \mathrm{~cm}(2$ in.) "FLEXCORE"

HONEYCOMB WITH

$0.6 \mathrm{~cm}(1 / 4 \mathrm{in}$.

EQUIVALENT CELL

SIZE EPOXIED TO SPOTWELD AT EDGE

$0.04 \mathrm{~cm}(0.0155$ in.) $0 \mathrm{~N} 0.3 \mathrm{~cm}$ CENTERS

$\ulcorner 9$ SECTIONS WITH

304 S. STEEL-

둰쥬

$01,234 \mathrm{~cm}$

$0.5 \quad 1 \quad 1.5$ in.

(a)

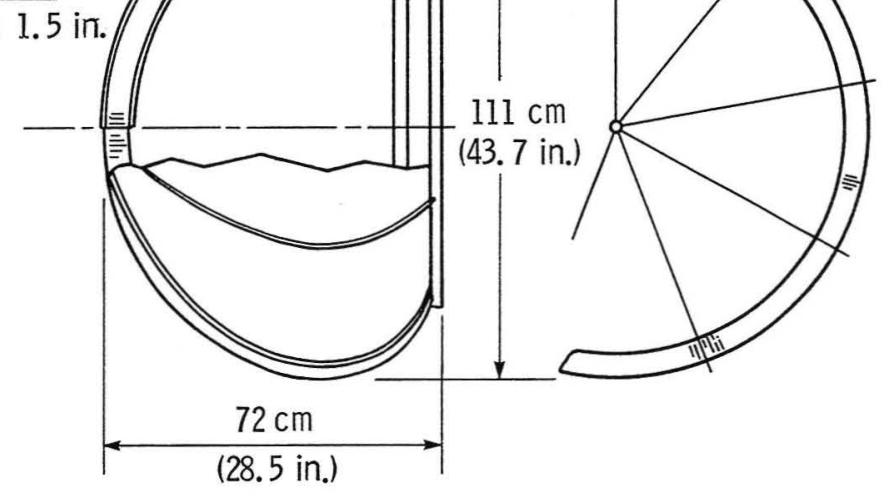

(b)

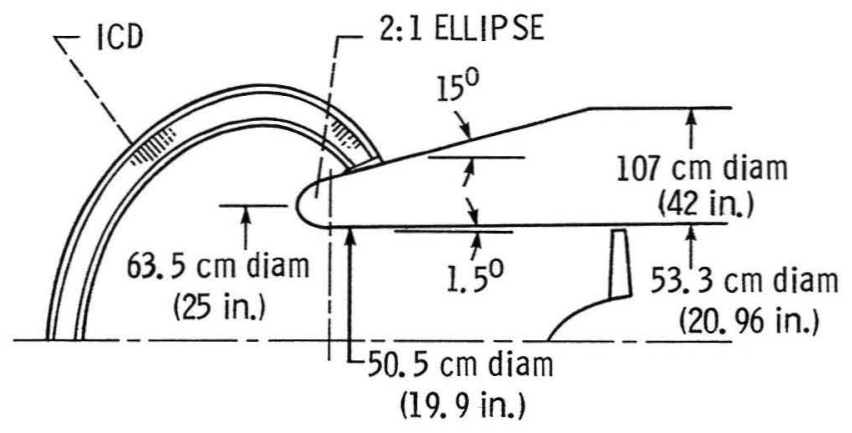

(a) Compact ICD design (2 fan diameter).

(b) ICD on cowled engine inlet.

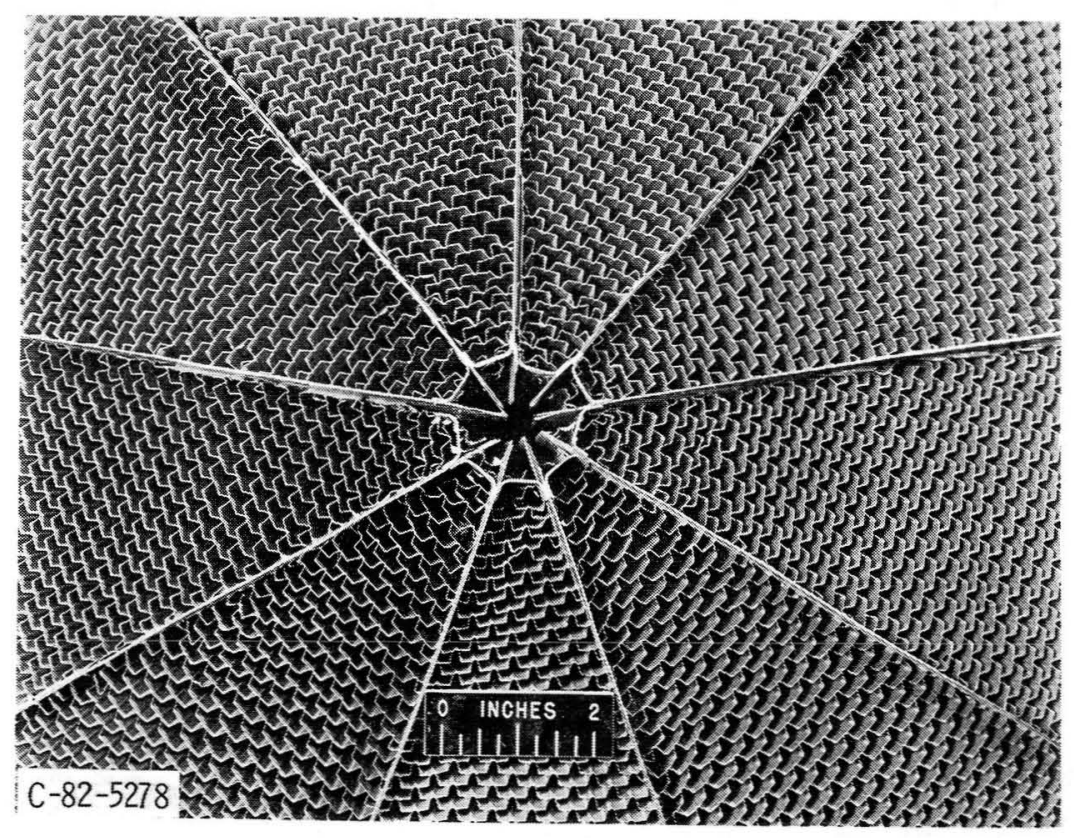

Figure 2. - Thin ribs of ICD.

Figure 1. - ICD, inlet and inlet cowling for JT15D-1 turbofan engine. 


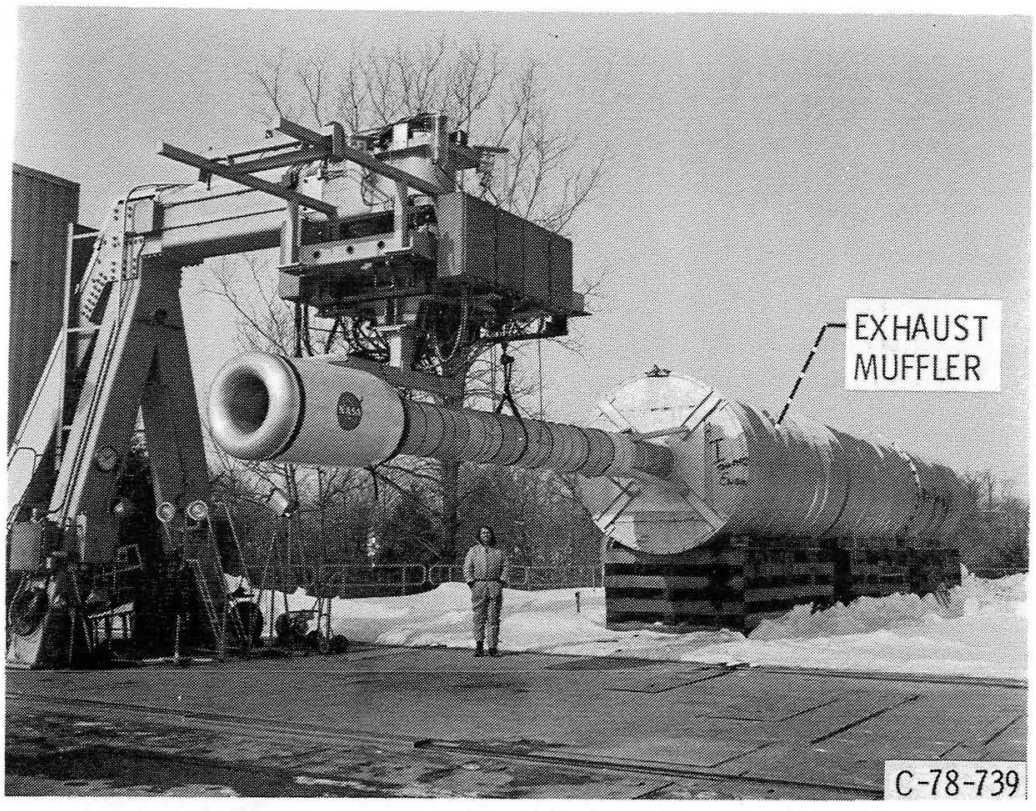

Figure 3. - JT15D-1 engine and exhaust muffler.

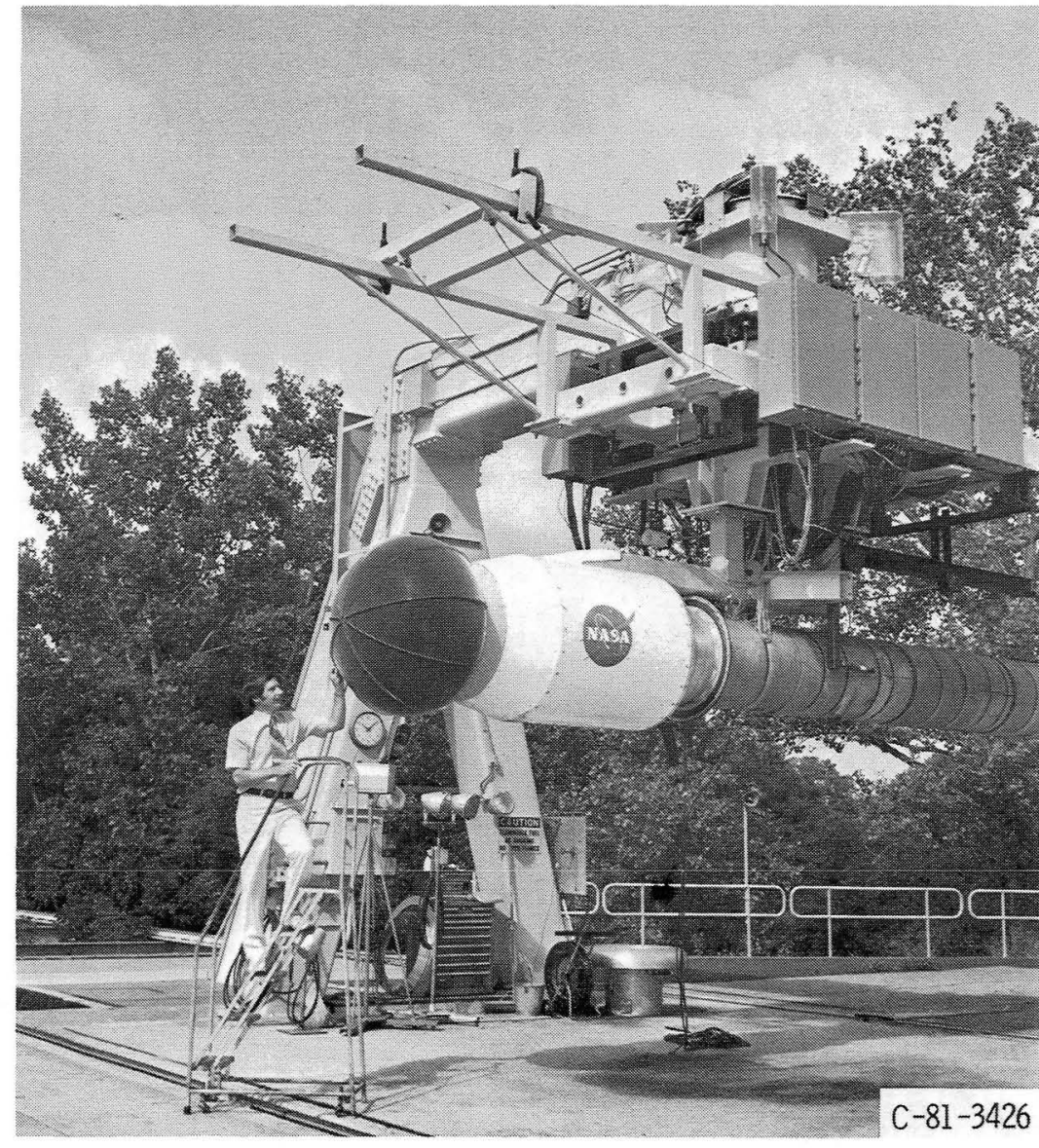

Figure 4. - JT15D-1 engine with compact ICD on acoustic test stand at NASA Lewis Research Center. 


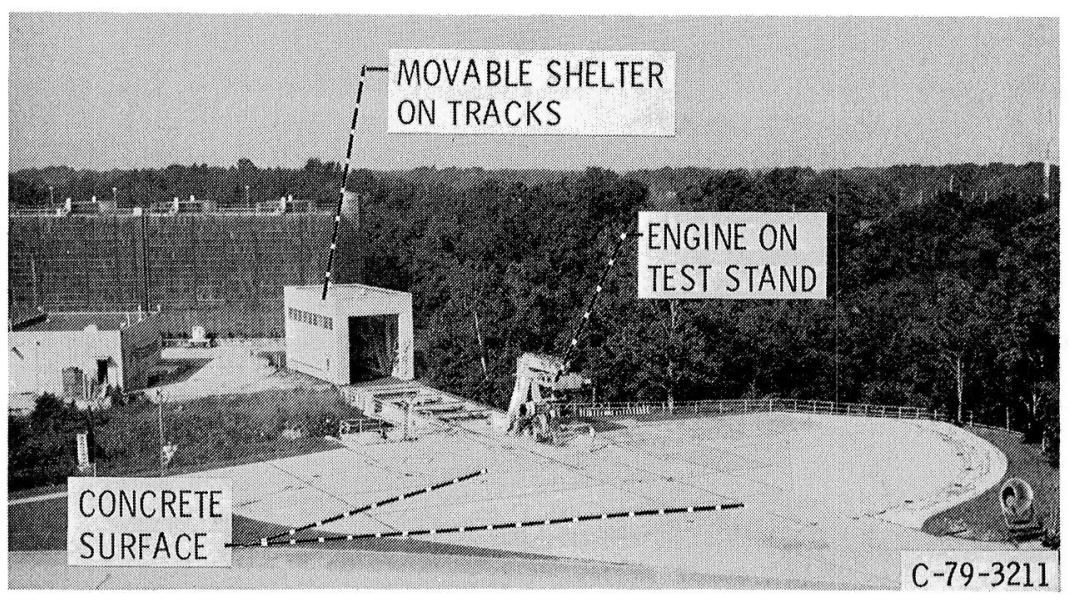

Figure 5. - Acoustic arena at NASA Lewis Research Center.

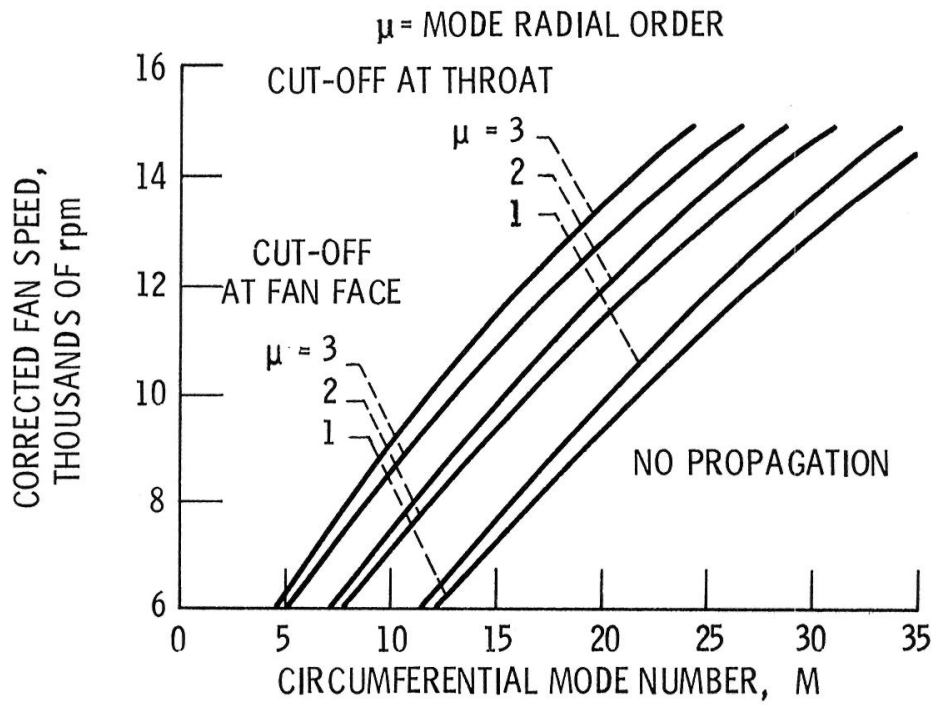

Figure 6. - BPF mode propagation for JT15D-1 engine with flight inlet. 

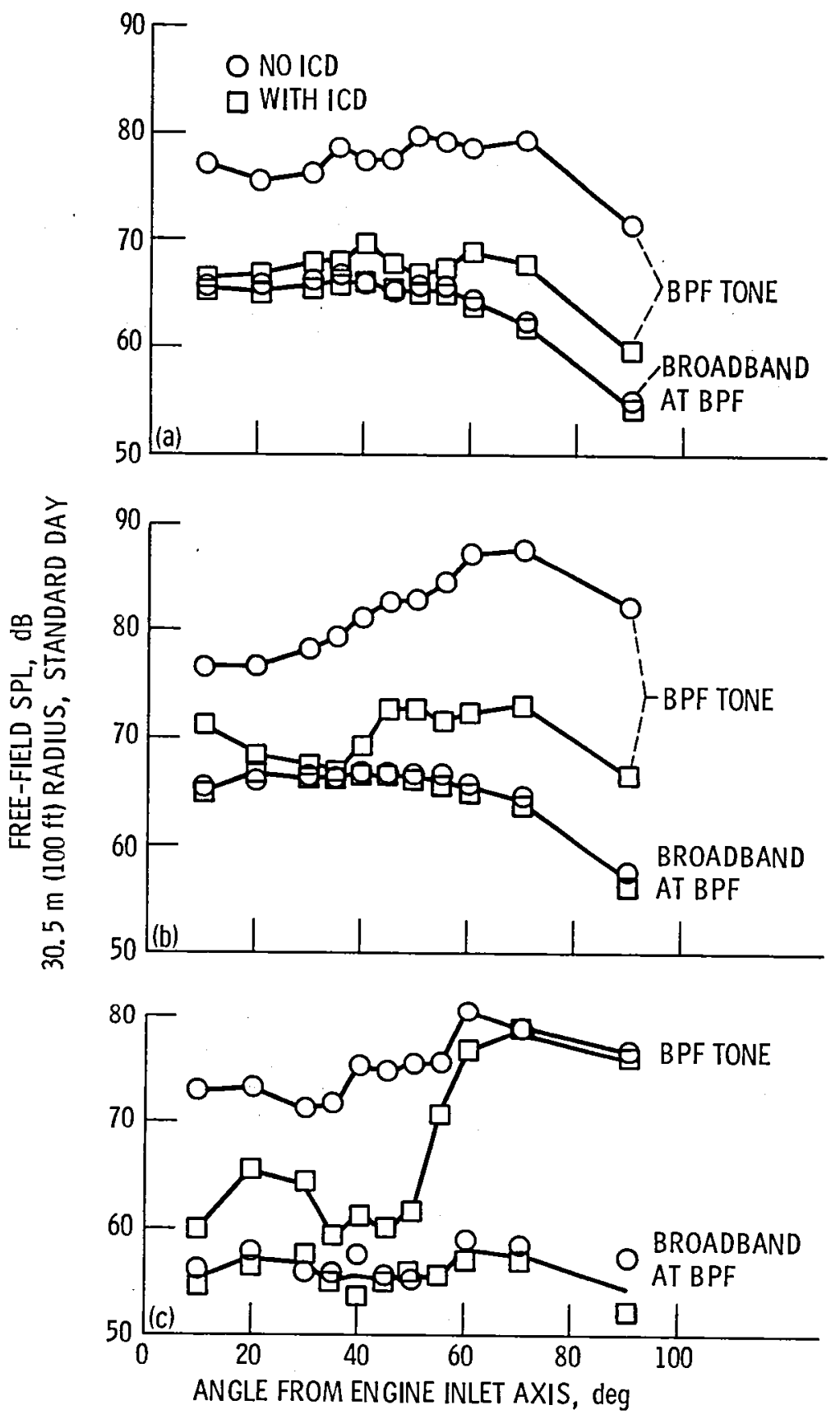
(a) Fan speed, $9700 \mathrm{rpm}$.
(b) Fan speed, $10800 \mathrm{rpm}$.
(c) Fan speed, $13500 \mathrm{rpm}$.

Figure 7. - Farfield directivity patterns, $25 \mathrm{~Hz}$ narrow band width. 


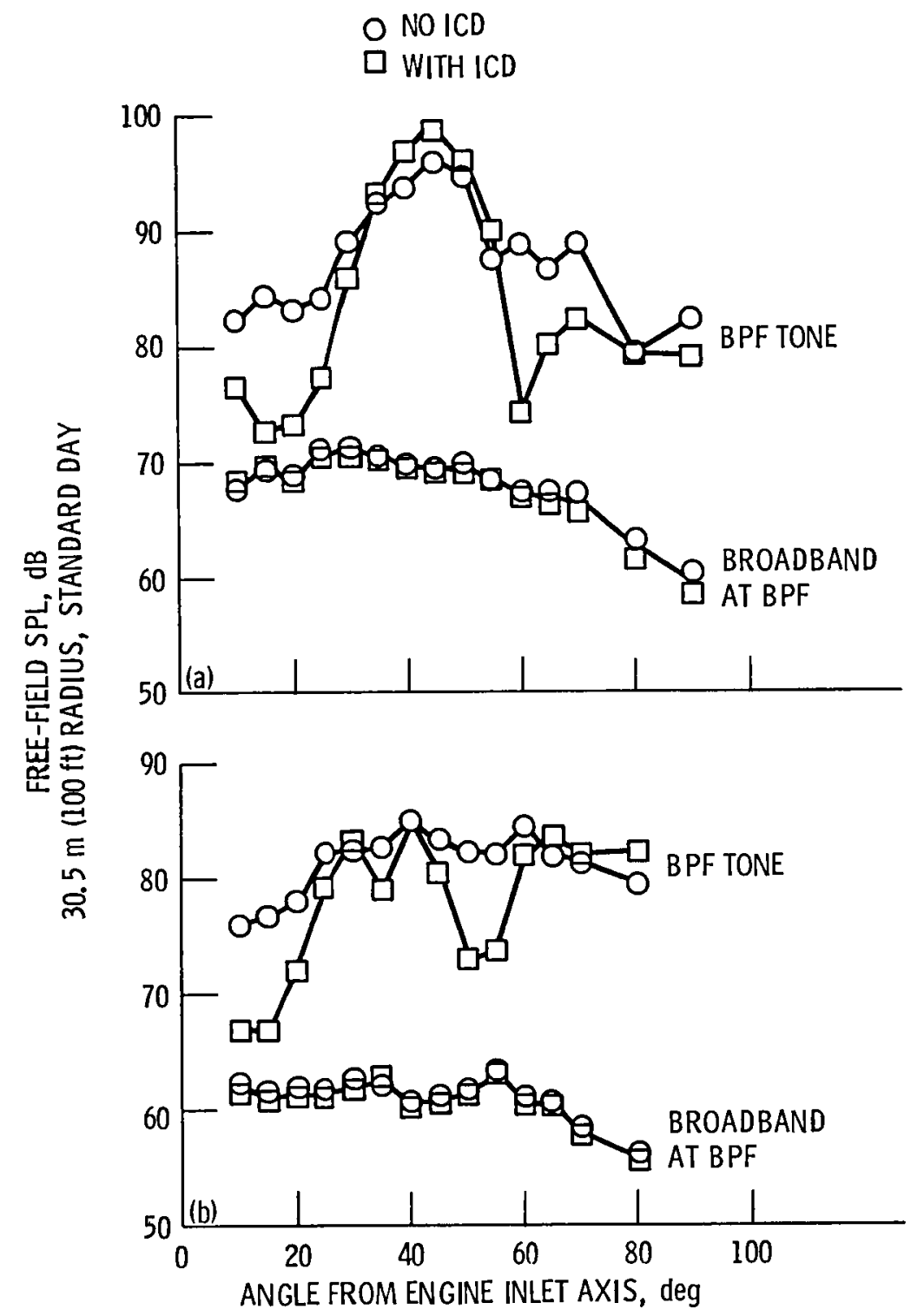

(a) Fan speed, $10800 \mathrm{rpm}$.

(b) Fan speed, $13500 \mathrm{rpm}$.

Figure 8. - Farfield directivity pattern associated with 41 rods.
B3 POWER SPECTRUM

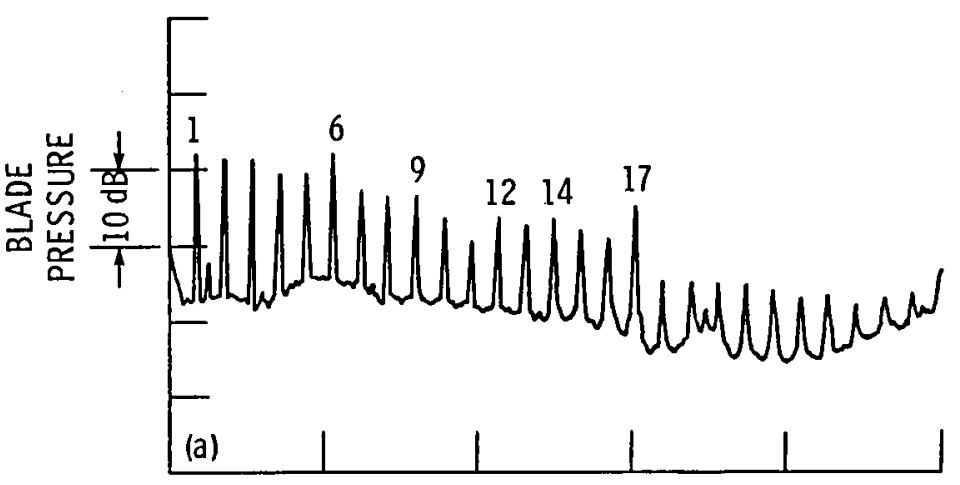

B3 POWER SPECTRUM
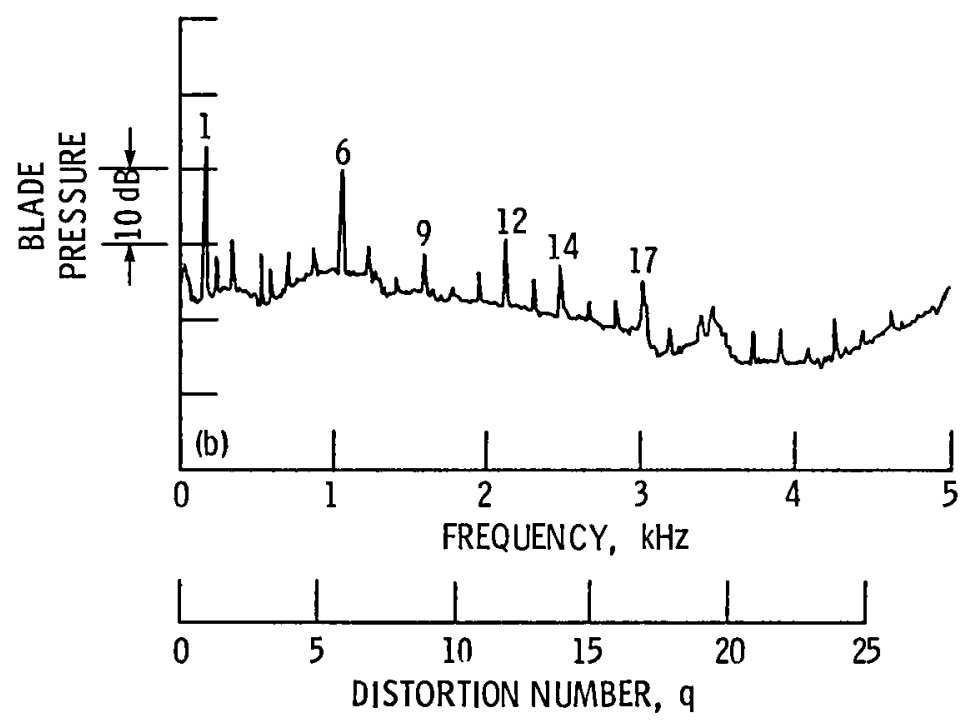

(a) No ICD.

(b) With compact 9-RIB ICD.

Figure 9. - Frequency spectra - (B3) blade mounted dynamic pressure transducer for $10500 \mathrm{rpm}$ at 6.25 $\mathrm{Hz}$ narrow band width. 
B3 POWER SPECTRUM

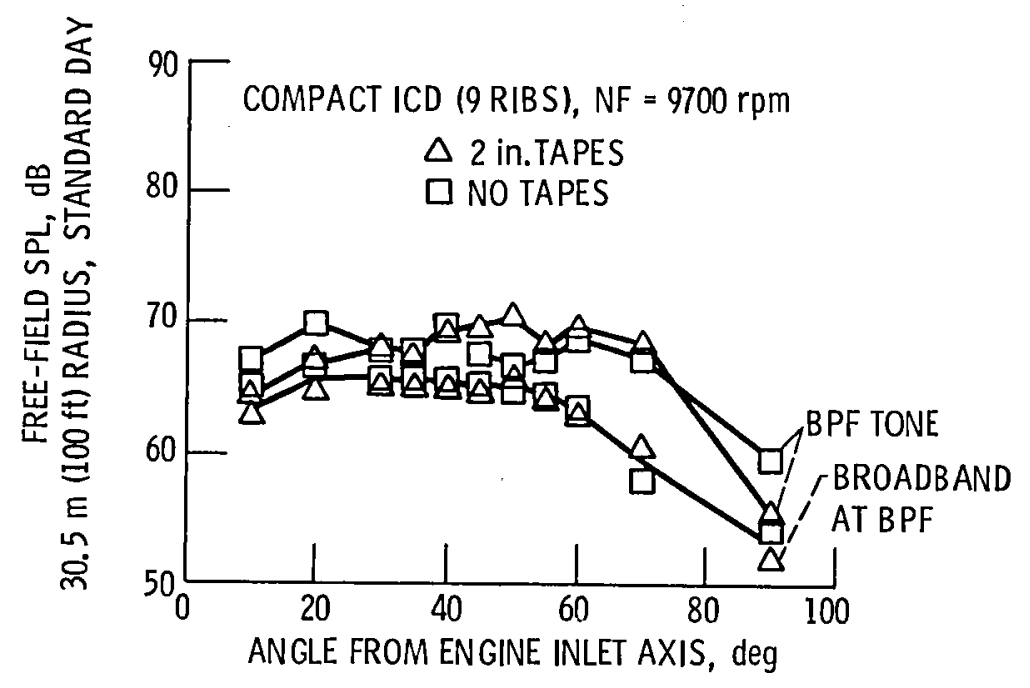

Figure 10. - Directivity pattern change by tape strips on ribs.

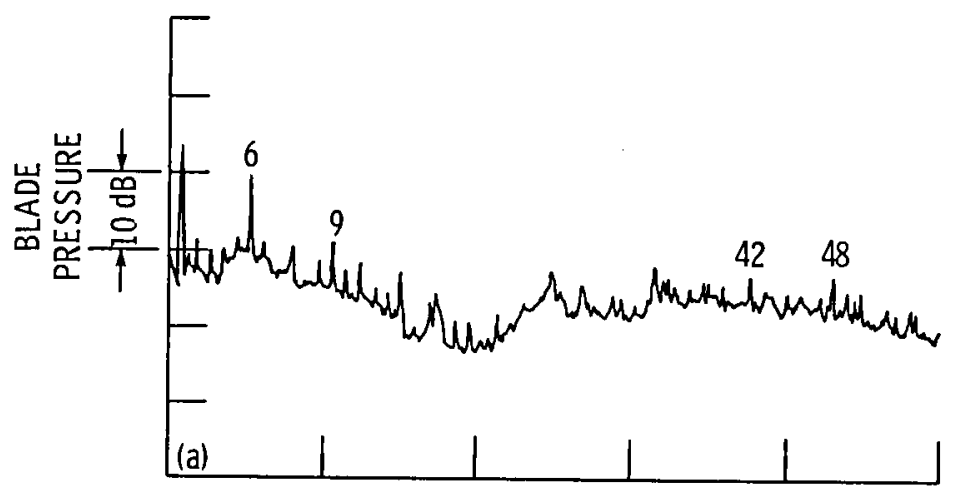

B3 POWER SPECTRUM

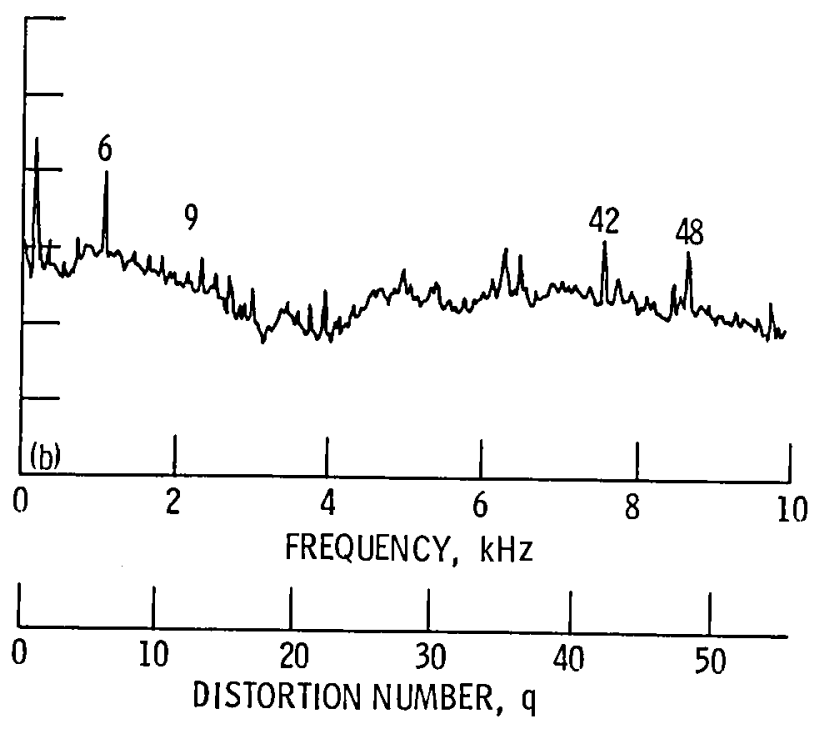

(a) Compact ICD - no tape on ribs.

(b) Compact ICD - 2 in. tape on nine ribs.

Figure 11. - Effect of wide rib simulation on frequency spectra from (B3) blade mounted dynamic pressure transducer, $100500 \mathrm{rpm}$. 


\begin{tabular}{|c|c|c|c|c|}
\hline $\begin{array}{ll}\text { 1. Report No. } & \text { NASA TM }-83349 \\
& \text { AIAA -83-0680 }\end{array}$ & \multicolumn{2}{|c|}{ 2. Government Accession No. } & \multicolumn{2}{|c|}{ 3. Recipient's Catalog No. } \\
\hline \multirow{2}{*}{\multicolumn{3}{|c|}{$\begin{array}{l}\text { 4. Title and Subtitle } \\
\text { A COMPACT INFLOW CONTROL DEVICE FOR SIMULATING } \\
\text { FLIGHT FAN NOISE }\end{array}$}} & \multicolumn{2}{|l|}{ 5. Report Date } \\
\hline & & & \multicolumn{2}{|c|}{$\begin{array}{l}\text { 6. Performing Organization Code } \\
505-31-32\end{array}$} \\
\hline \multirow{2}{*}{\multicolumn{3}{|c|}{$\begin{array}{l}\text { 7. Author(s) } \\
\text { L. Homyak, J. G. McArdle, and L. J. Heidelberg }\end{array}$}} & \multicolumn{2}{|c|}{$\begin{array}{l}\text { 8. Performing Organization Report No. } \\
\text { E-1606 }\end{array}$} \\
\hline & & & \multirow{2}{*}{\multicolumn{2}{|c|}{ 10. Work Unit No. }} \\
\hline \multirow{3}{*}{\multicolumn{3}{|c|}{$\begin{array}{l}\text { 9. Performing Organization Name and Address } \\
\text { National Aeronautics and Space Administration } \\
\text { Lewis Research Center } \\
\text { Cleveland, Ohio } 44135\end{array}$}} & & \\
\hline & & & \multicolumn{2}{|c|}{ 11. Contract or Grant No. } \\
\hline & & & \multicolumn{2}{|c|}{$\begin{array}{l}\text { 13. Type of Report and Period Covered } \\
\text { Technical Memorandum }\end{array}$} \\
\hline \multicolumn{3}{|c|}{$\begin{array}{l}\text { 12. Sponsoring Agency Name and Address } \\
\text { National Aeronautics and Space Administration } \\
\text { Washington, D.C. } 20546\end{array}$} & \multicolumn{2}{|c|}{ 14. Sponsoring Agency Code } \\
\hline \multicolumn{5}{|c|}{$\begin{array}{l}\text { 15. Supplementary Notes } \\
\text { Prepared for the Eighth Aeroacoustics Conference sponsored by the American Institute of } \\
\text { Aeronautics and Astronautics, Altanta, Georgia, April 11-13;1983. }\end{array}$} \\
\hline \multicolumn{5}{|c|}{$\begin{array}{l}\text { 16. Abstract } \\
\text { Inflow control devices (ICD's) of various shapes and sizes have been used to simulate inflight } \\
\text { fan tone noise during ground static tests. A small, simple inexpensive ICD design was optimized } \\
\text { from previous design and fabrication techniques. This compact two-fan-diameter ICD exhibits } \\
\text { satisfactory acoustic performance characteristics without causing noise attenuation or redirec- } \\
\text { tion. In addition, it generates no important new noise sources. Design and construction details } \\
\text { of the compact ICD are discussed and acoustic performance test results are presented. }\end{array}$} \\
\hline \multicolumn{2}{|c|}{$\begin{array}{l}\text { 17. Key Words (Suggested by Author(s)) } \\
\text { Inflow control; Flight effects; Ground testing; } \\
\text { Static tests; Simulate flight tests; Compact ICD }\end{array}$} & \multicolumn{3}{|c|}{$\begin{array}{l}\text { 18. Distribution Statement } \\
\text { Unclassified - unlimited } \\
\text { STAR Category } 71\end{array}$} \\
\hline $\begin{array}{l}\text { 19. Security Classif. (of this report) } \\
\text { Unclassified }\end{array}$ & \multicolumn{2}{|c|}{$\begin{array}{r}\text { 20. Security Classif. (of this page) } \\
\text { Unclassified }\end{array}$} & 21. No. of Pages & 22. Price" \\
\hline
\end{tabular}

*For sale by the National Technical Information Service, Springfield, Virginia 22161 

, 
National Aeronautics and Space Administration

Washington, D.C.

20546

Official Business

Penalty for Private Use, $\$ 300$
SPECIAL FOURTH CLASS MAIL BOOK

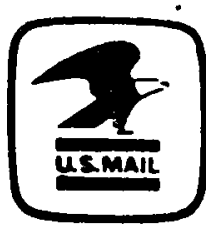

Postage and Fees Paid

National Aeronautics and Space Administration NASA-451

1

DO NOT REMOVE SLIP FROM MATERIAL Delete your name from this slip when returning material
to the library.
If Undeliverable (Sectinn 154

Postal Manuall [xo Nul Return

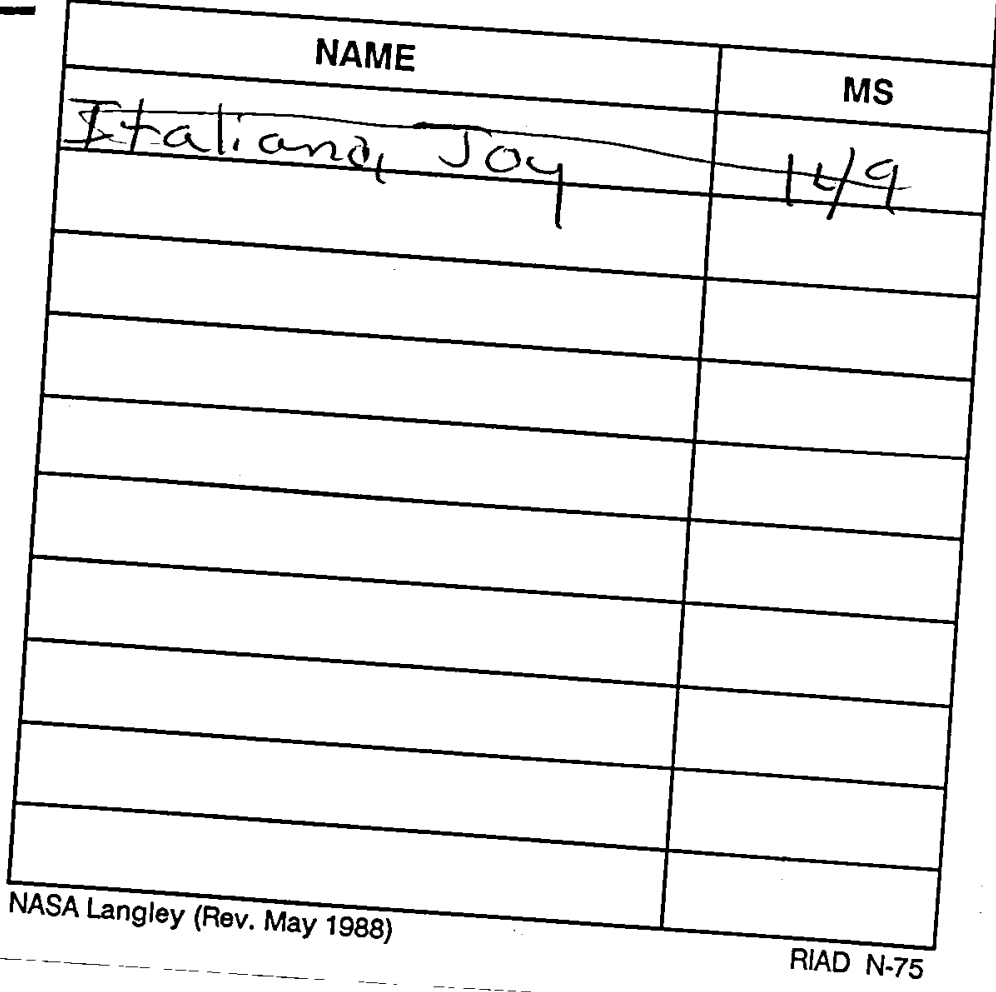

